\title{
Snapshot of Technology Business Incubators in China
}

\author{
Nasir Mahmood ${ }^{1} *$, Cai Jianfeng ${ }^{1}$, Farhan Jamil ${ }^{2}$, Hina Munir ${ }^{1}$, Jintao LU ${ }^{1}$, \\ Mustafa Khan ${ }^{1}$ and Yue Cai ${ }^{3}$ \\ ${ }^{1}$ School of Management, Northwestern Polytechnical University, Xi'an, 710072 \\ Shannxi, P.R. China \\ ${ }^{2}$ Department of Management, Universiti Teknologi Malaysia, 81310, Malaysia \\ ${ }^{3}$ Brock University, Canada \\ *nasirmahmood@mail.nwpu.edu.cn
}

\begin{abstract}
In the contemporary world, the production of suitable goods and commodities and business developments, the business technology incubators are considered important for the inception of new ideas and combining them with the available resources. Similarly, business and technology incubators are considered a backbone to accelerate the innovation and new business development structure of national economies. The business incubators in China are flourishing by leaps and bounds since the mid of 1990s. This paper aims to explore the performance of technology business incubator in china. In this study the incubator data which was compiled by Ministry of Science and Technology (MOST) China was taken for performance evaluation in china. The performance of incubator in 2002 and in 2012 was assessed by comparison of total number of tenants, total income of tenants, number of graduated tenants and number of employees of tenants, further, in 2012 the association of number of invention patent with the accumulated number of tenants obtained investment and finance is assessed, and this paper also presents the graduated firms number every year in China. These results show that the performance of technology incubators is increased during the last decade.
\end{abstract}

Keywords: Business Incubator, business incubation performance, innovation, tenants, China

\section{Introduction}

In the present day world, syndicates that have an attention on growing advanced products and novelty are organizations with higher profit volumes and this converts into higher salaried earnings for employees in innovative organizations (Galor and Zeira 1993). In the recent and wide acknowledgment, technology and innovation are considered significant performance elements of the national economy with the development of knowledge based economy (Lundvall, Johnson, et al., 2002; Rooney, Hearn, et al., 2012). In business economy there are number of business organizations and the success of these organizations is dependent on their ability to innovate; business unit lacking this skill are rising finding themselves lacking a mechanism that allow them to persist competitive and grow in high wage and profit businesses (Grossman 1993). Innovation is the basis for increased output, competitiveness and national wealth(Carlson and Wilmot 2006). Carlson and Wilmot (2006) further specified that innovation is the effective creation and transfer of a new or developed product, process or service in the market place. In other words, it is the procedure of development and positioning of new products, processes and business models for economic advantages notwithstanding of whether they are new to their opponents, countries, or the world (Bounfour, Bismuth, et al., 2008). Innovation is reliant on the conception and origin of new knowledge in the present economy and it is mostly realized by the research, thus research based novelty is deliberated to be a highly 
valued commodity in the modern economy as it is anticipated that research based innovation creates new economic activity and increases the existing wealth (Parto 2008). Likewise organizations are also considering methods of influencing the strategies and procedures for improved levels of innovation (see Figure1).

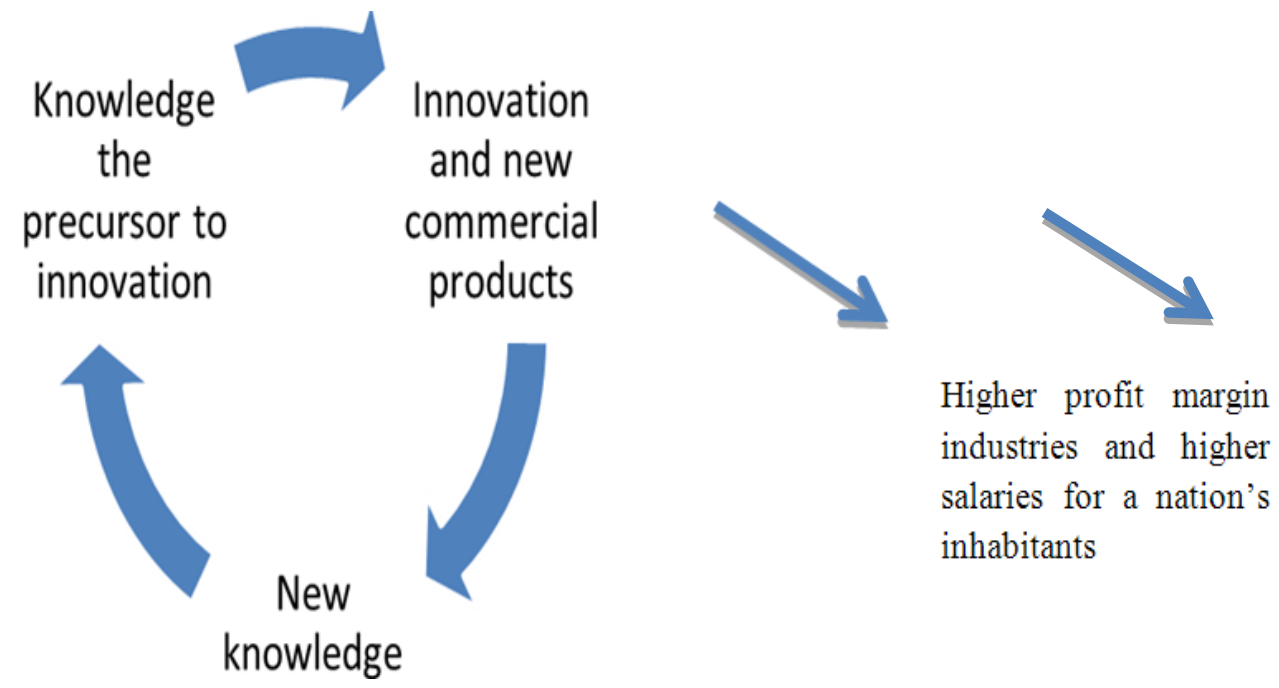

(Yee 2009)

\section{Defining Business Incubation}

In view of the literature on business incubation, it can be broadly categorized in to two realms: academic based and industry based. Scholars have primarily concentrated on the evolution of incubation and on a specific element to the process (Tötterman and Sten 2005; Hughes, Ireland, et al., 2007; Ascigil and Magner 2009). Incubator associations like UK Business Incubation (UKBI) and the National Business Incubation Association (NBIA), as well as various consultancy firms have focused their attention on incubators and the positive impact they have on new start-ups and on the economic environment, through evaluation studies and identification of best practice.

Broadly speaking technology incubator can be describes as it is an individual whose main focus is on innovation and which enhances innovation in the economy (Mahmood, N,Jianfeng Cai 2015). A former definition of an incubator is a defined physical place Gonzalez and Lucea (2001), where services are accessible. In this definition, the incubator is an individual comprising of organized geographical or essential area that helps new start-up projects and new companies till they are capable to be self -sufficient by means of orthodox business funds. Incubator features are distinct as on-location supervision and management properties, marketing, geographical space, public IT facilities and entrance to funding or start-up capital for business development. In another definition Business incubators can be defined as that "constitutes an environment, especially designed to hatch enterprises. They provide their tenant companies with several facilities, from office space and capital to management support and knowledge. This allows the start-up to concentrate on its business plan and raises the success rate"(Aerts, Matthyssens, et al., 2007)

Lastly, the technology incubator can be defined Phan, Siegel, et al., (2005) as an entity which emphases on its relationship with the conception of knowledge and innovation. This definition explains the technology incubator in the context of physical location that assists to syndicate knowledge; innovation and knowledge management in order to increase products and worthwhile business individuals (see Figure 2). 


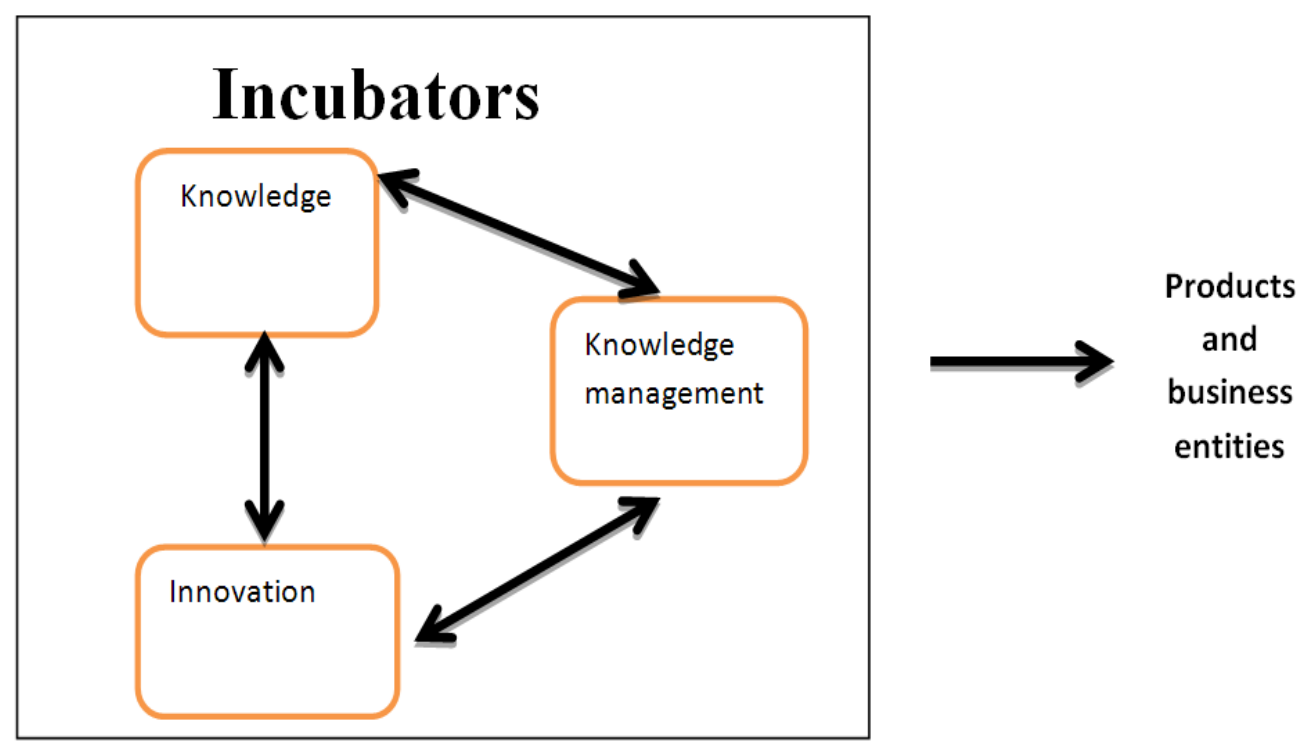

Figure 1. Knowledge Transformed To Produce Innovation and Products in an Incubator

\section{Performance of Business Incubator}

There is no defined and single explained standard to measure incubator performance (Phan, Siegel, et al., 2005). Incubator performance measures are a commonly discussed issue and have become one of the most debatable points among researchers; Literature broadly agrees that no clear harmony exists on what establishes an appropriate measure of performance (Rice 2002; Phan, Siegel, et al., 2005).

Evaluating the achievement and influence of incubators is essential because insofar as incubators utilize Govt. and venture capitalist resources, they are responsible for the results of the distribution and use of those resources (Hackett and Dilts 2004). In what manner business incubators are assessed is of great value so as to provide assistance for best preparation to investor groups involved with their formation and action (Schwartz and Göthner 2009).

A major supporter to the nonexistence of consensus among researchers with regard to the success of incubators is because of the lack of a definite measure of incubator effectiveness. In literature there is no consensus agreement about defining the performance and the appropriate method for the valuation and assessment. (Mian 1997; Bergek and Norrman 2008)

Bergek and Norrman (2008) define performance as to the extent in which incubator consequences match to the objectives of the incubator. Archetypally, incubator programs will have aims and intentions that show their own certain effective situation and investors' benefits (Al-Mubaraki and Busler 2011). Notwithstanding a wide area of research concentrating on the results of incubators programs and methods to examine incubator performance, still, there is little consensus in what way to determine which incubators are more result oriented than others (Schwartz and Göthner 2009).

There were several studies which discussed various measures and indicators that may be used to determine incubator performance or effects (M'Chirgui 2012). Al-Mubaraki and Wong (2011) assesses incubators corresponding to four main performance measures: the total number of, companies made with the funding of an incubator, graduated companies, capitalists sponsored, jobs created.

The Rothaermel and Thursby (2005) assesse the university based incubators firm knowledge streams on the performance of tenant, revenues generated, total funds raised, 
venture capital funding obtained and whether the firm graduated, failed, or stayed in the incubator.

From their literature review Allen and McCluskey (1990) mentioned various measures: tenant engagement, incubator period, and renter success rate, local retention of graduates and auxiliary value of incubator services. In addition to this they assess incubator size and tenancy rate, jobs generated and companies graduated. The performance of tenant by auxiliary value of science parks is investigated by increase in employment sales and effectiveness (Löfsten and Lindelöf 2002).

\section{Types of Incubators}

Incubators are mostly categorized, how they are financing and utilize their funds to grow the incubator; the followings types of them are as follows-

Real estate development enterprises - These incubators used the concept that the organizations that employed them remain within the real estate park develop themselves high paying high value tenants.

Academic - The purpose of these incubators is as same as for profit incubators apart from the academy is the source of finance that demands the return on finance and are also called as public for-profit incubators.

Non-profit - They function in the similar manner as the other incubators however they do not necessitate that money is returned from the new firm contained by the incubator to the incubator or the investor that provides the finance.

For-profit - The subscriber will have necessities such as yield on investment in the beginning or stock alternatives in the commercial private for-profit incubator (Martin 1997).

\section{Methodology}

The methodology adopted is mainly quantitative approach; the secondary data was obtained, which contains valuable information of all technology business incubators of china during 2002-2012, from Ministry of Science and Technology (MOST) China. The details regarding the variables, which were assimilated to depict the performance of the incubators in china, are 1) number of tenants, 2) total income of tenants, 3) accumulated number of graduated tenants and 4) number of employees of tenants. Comparison of the variables, which were adapted, is shown in the Table I, which depicts the performance of the business incubators. To access the performance another measure is adopted in this article which is to show the number of graduated tenants in the last five years which is presented in Table II.

\section{Analysis and Results}

In this paper the analysis and results section consists of three analyses in order to assess the performance of incubators in China. The performance is evaluated by considering the data at different time periods say 2002-2012. Different variables are obtained in this context from the data compiled by the Ministry of Science and Technology (MOST) China. The statistic which was used in this paper was number of TBIs and their income, graduated tenants and their employees.

In this paper the relationship of tenants obtained investment and finance and number of patents these tenants produced id also described while using he chi- square analysis.

Lastly, the number of graduated firms' is taken in this paper for in the recent five years shown in the Table III. 
Table I

\begin{tabular}{|l|c|c|c|}
\hline \multicolumn{1}{|c|}{ Incubator statistic } & $\begin{array}{c}\text { Amount } \\
\text { In 2002 }\end{array}$ & $\begin{array}{c}\text { Amount in } \\
\mathbf{2 0 1 2}\end{array}$ & \% increase \\
\hline Number of TBIs (unit) & 378 & 1239 & 30.51 \\
\hline Number of Tenants (unit) & 20993 & 70217 & \\
\hline $\begin{array}{l}\text { Total Income of Tenants (100 } \\
\text { million yuan) }\end{array}$ & $1: 55$ & $1: 57$ & 15.25 \\
\hline $\begin{array}{l}\text { Accumulated Number } \\
\text { of Graduated Tenants (unit) }\end{array}$ & 230.5 & 4958.3 & 13.7 \\
\hline $\begin{array}{l}\text { Number of Employees of } \\
\text { Tenants (person) }\end{array}$ & $1: 0.61$ & 45160 & \\
\hline
\end{tabular}

Above Table is comprised of statistic showing to the performance of tenants and their eventual outcome on incubator performance. In table I the performance of incubators is evaluated in two years and their results show the increase in performance of tenants. In 2002 there were 378 technology incubators in china and in 2012 the number of incubators has increased to 1239. Number of tenants in 2002, the ratio of 1:55 and in 2012 the ratio is 1:57 which shows the $30 \%$ increase in number of tenants. Total income of tenants shows the value as 1:0.61 in 2002, and in 2012 the value of incubator income is 1:4 which shows $15.25 \%$ increase in income. Accumulated number of graduated tenants in 2002 was 1:16; however, in 2012 it increases to 1:36 which depicts $13.7 \%$ increase in number of graduated tenants since last decade. There were 1:960 employees per incubator in 2002 and 1:1160 employees in 2012 that shows a $25 \%$ increase in number of employees of tenants.

In Table II the chi-square statistic is run with the variables accumulated number of tenants obtained investments and finance and number of invention patents. These results indicates that those tenants who were obtained investment and finance and how much they produce the number of patents in that particular time period. Squicciarini (2008) in her study examines patent activity for assessment of performance Finish science park businesses. In Table II the relationship between numbers of Patents produced in China during 2012 is significant as there is association between these two variables in the study.

Table II

\begin{tabular}{|l|r|r|}
\hline \multicolumn{3}{|c|}{ Test Statistics } \\
\hline & $\begin{array}{c}\text { Number of Invention Patent } \\
\text { (piece) }\end{array}$ & $\begin{array}{l}\text { Accumulated Number of tenants } \\
\text { obtained Investment and finance } \\
\text { (unit) }\end{array}$ \\
\hline Chi-Square & 573.090 & 419.144 \\
\hline Asymp. Sig. & .000 & .000 \\
\hline
\end{tabular}


Table III

\begin{tabular}{|l|l|}
\hline Year & Accumulated Number of Graduated Tenants \\
\hline 2007 & 17588 \\
\hline 2008 & 25656 \\
\hline 2009 & 24513 \\
\hline 2010 & 28659 \\
\hline 2011 & 30471 \\
\hline 2012 & 36,020 \\
\hline
\end{tabular}

In Table III the number of graduated firms is shown and this Table adds valuable information as number of graduated firms is increasing every year except the year 2009. It shows that the incubators performance is increasing every year in China. The average number of graduates per year shows the comprehensive efficiency of the BIs in response to the fundamental incubator purpose and the acceleration in the innovative development (Peters, Rice, et al., 2004) (Allen and McCluskey 1990).

\section{Conclusion}

This paper indicates and concludes that for the evaluation and assessment of the performance of business incubator no specific and defined methods are explained in literature. Various researchers use different methods and models to evaluate the performance of business incubators. In this paper the performance of incubators is evaluated through the tenant performance, patent produces and graduated firms in China. Findings of the study show that the performance is increasing every year, as the number of graduated firms increasing, patents have significant relationship with tenants obtained investment and finance. The average number of graduates per year shows the comprehensive efficiency of the BIs in response to the fundamental incubator purpose and the acceleration in the innovative development (Peters, Rice, et al., 2004).

This research also tries to enlighten that incubator performance enhances by transfer of knowledge and innovation and that is dependent on the managers and tenants. In the present era the innovation and technology cannot be neglected for the development of business and economy as a whole. Only those business organizations are successful now a day which have ability to innovate and which are creating new products and have ability for being competitive in the economy. Business incubators and technology business incubators are linked with the ability to innovate and creation of knowledge and enhance the innovation in the economy and through with the national economy flourishing worldwide.

\section{References}

[1] K. Aerts and P. Matthyssens, "Critical role and screening practices of European business incubators", Technovation, vol. 27, no. 5, (2007), pp. 254-267.

[2] H. Al-Mubaraki and M. Busler, "The incubators economic indicators: Mixed approaches", Journal of Case Research in Business and Economics, vol. 4, (2011), pp. 1-12.

[3] H. Al-Mubaraki and S. F. Wong, "How valuable are business incubators? A case illustration of their performance indicators", European, Mediterranean \& Middle Eastern Conference on Information Systems (EMCIS), (2011).

[4] A. McCluskey, N. David and R. McCluskey, "Structure, Policy,Services, and Performance in the Business Incubator Industry", Entrepreneurship Theory and Practice, vol. 15, (1990), pp. 61.

[5] S. F. Ascigil and N. R. Magner, "Business incubators: leveraging skill utilization through social capital", Journal of Small Business Strategy, vol. 20, no. 1, (2009), pp. 19. 
[6] A. Bergek and C. Norrman, "Incubator best practice: A framework", Technovation, vol. 28, no. 1, (2008), pp. 20-28.

[7] A. Bounfour and A. Bismuth, "Creating value from intellectual assets", Journal of Intellectual Capital, vol. 9, no. 2, (2008), pp. 228-245.

[8] C. R. Carlson and W. W. Wilmot, "Innovation: The five disciplines for creating what customers want", Crown Business, (2006).

[9] O. Galor and J. Zeira, "Income distribution and macroeconomics", The review of economic studies, vol. 60, no. 1, (1993), pp. 35-52.

[10] M. Gonzalez and R. Lucea, "The evolution of business incubation", Center for Economic Development, Carnegie Mellon University, (2001).

[11] G. M. Grossman, "Innovation and growth in the global economy", MIT press, (1993).

[12] S. M. Hackett and D. M. Dilts, "A real options-driven theory of business incubation", The Journal of Technology Transfer, vol. 29, no. 1, (2004), pp. 41-54.

[13] M. Hughes and R. D. Ireland, "Stimulating dynamic value: Social capital and business incubation as a pathway to competitive success", Long Range Planning, vol. 40, no. 2, (2007), pp. 154-177.

[14] H. Löfsten and P. Lindelöf, "Science Parks and the growth of new technology-based firms-academicindustry links, innovation and markets", Research policy, vol. 31, no. 6, (2002), pp. 859-876.

[15] B.-A. Lundvall and B. Johnson, "National systems of production, innovation and competence building", Research policy, vol. 31, no. 2, (2002), pp. 213-231.

[16] Z. M'Chirgui, "Assessing the Performance of Business Incubators: Recent France Evidence", Business and Management Research, vol. 1, no. 1, (2012), pp. 62.

[17] N. Mahmood, C. Jianfeng and F. Jamil, "Business Incubators: Boon or Boondoggle for SMEs and Economic Development of Pakistan", International Journal of u- and e- Service, Science and Technology, vol. 8, no. 4, (2015), pp.147-158, http://dx.doi.org/10.14257/ijunesst.2015.8.4.15.

[18] F. Martin, "Business incubators and enterprise development: Neither tried or tested?", Journal of Small Business and Enterprise Development, vol. 4, no. 1, (1997), pp. 3-11.

[19] S. A. Mian, "Assessing and managing the university technology business incubator: an integrative framework", Journal of Business Venturing, vol. 12, no. 4, (1997), pp. 251-285.

[20] S. Parto, "Innovation and economic activity: an institutional analysis of the role of clusters in industrializing economies", Journal of economic issues, (2008), pp. 1005-1030.

[21] L. Peters and M. Rice, "The role of incubators in the entrepreneurial process", The Journal of Technology Transfer, vol. 29, no. 1, (2004), pp. 83-91.

[22] P. H. Phan and D. S. Siegel, "Science parks and incubators: observations, synthesis and future research", Journal of Business Venturing, vol. 20, no. 2, (2005), pp. 165-182.

[23] M. P. Rice, "Co-production of business assistance in business incubators: an exploratory study", Journal of Business Venturing, vol. 17, no. 2, (2002), pp. 163-187.

[24] D. Rooney and G. Hearn, "Knowledge is people doing things, knowledge economies are people doing things with better outcomes for more people", Handbook on the knowledge economy, volume two. Edward Elgar, Cheltenham and Northampton, (2012), pp. 1-14.

[25] F. T. Rothaermel and M. Thursby, "Incubator firm failure or graduation?: The role of university linkages", Research policy, vol. 34, no. 7, (2005), pp. 1076-1090.

[26] M. Schwartz and M. Göthner, "A multidimensional evaluation of the effectiveness of business incubators: an application of the PROMETHEE outranking method", Environment and Planning C: Government and Policy, vol. 27, no. 6, (2009), pp. 1072-1087.

[27] M. Squicciarini, "Science Parks' tenants versus out-of-Park firms: who innovates more? A duration model", The Journal of Technology Transfer, vol. 33, no. 1, (2008), pp. 45-71.

[28] H. Tötterman and J. Sten, "Start-ups business incubation and social capital", International Small Business Journal, vol. 23, no. 5, (2005), pp. 487-511.

[29] N. G. Yee, "Technology Incubator Performance in New Zealand", Innovation Management, ICIM'09, International Conference on, IEEE, (2009).

\section{Author}

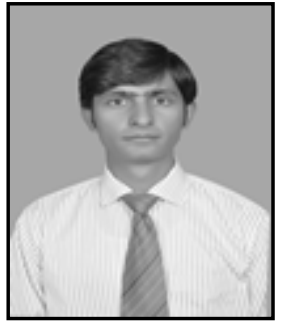

Nasir Mahmood, he is $\mathrm{PhD}$ scholar at School of Management, Northwestern Polytechnical University, Xi'an, 710072, Shaanxi, P.R. China. His research interests are mainly in the field of innovation management, entrepreneurship and Business incubators in particular the evaluation of strategies and University- industry technology transfer. His Email is nasirmahmood@mail.nwpu.edu.cn 
International Journal of $u-$ and $e-$ Service, Science and Technology Vol.8, No. 7 (2015) 